\title{
Effect of arbuscular mycorrhiza on the growth and development of micropropagated Annona cherimola plants
}

\author{
Concepcion Azcón-Aguilar, C. L. Encina, R. Azcón and Jose Miguel Barea \\ Azcón-Aguilar, C.' ', Encina, C. L. ${ }^{2}$, Azcón, R.' \& Barea, J. M.' 1994. Effect of \\ arbuscular mycorrhiza on the growth and development of micropropagated \\ Annona cherimola plants. Agricultural Science in Finland 3: 281-288. ('Estación

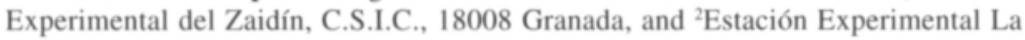 \\ Mayora, C. S. I. C., Málaga, Spain.)
}

\begin{abstract}
Annona cherimola Mill., cherimoya, is a tropical plantation crop of interest in fruit culture. Micropropagation techniques have been developed due to the need to increase productivity through clonal selection. Because of the mycorrhizal dependence exhibited by this crop for optimal growth and the recognized role of mycorrhiza establishment for the survival and development of most of the plants produced in vitro, the effect of mycorrhiza inoculation on the development of micropropagated plants of Annona cherimola was investigated.

Mycorrhizal inoculation was assayed at two different stages of the micropropagation process: (i) immediately after the in vitro phase, before starting the acclimatization period, and (ii) after the acclimatization phase, before starting the postacclimatization period under greenhouse conditions. Plantlet survival was about $50 \%$ after the acclimatization period. Plant growth and development profited remarkably from mycorrhiza establishment. Most of the arbuscular mycorrhizal fungi (AMF) assayed greatly increased shoot and root biomass and leaf area. Micropropagated Annona plants seem to be more dependent on mycorrhiza formation for optimal growth than plants derived from seeds. The greatest effects of AMF on plant growth were observed when they were introduced after the acclimatization period.
\end{abstract}

Key words: mycorrhizal dependence, micropropagation, Glomus species

\section{Introduction}

Annona cherimola Mill., cherimoya, a tropical tree native to South America, is of particular interest in fruit culture. It is well adapted to the subtropical conditions of Southern Spain where it is successfully cropped in the Granada and Malaga provinces (MORTON 1987). It belongs to the Annonaceae family of the Magnoliales (GAUSSEN et al. 1982) and, as most members of this order, it has a relatively unbranched root system, with thick roots lacking root hairs. This suggests the mycotrophic nature of this species. This fact has been corroborated in a preliminary study in which Annona showed a strong dependence on arbuscular mycorrhiza formation for optimal growth and development (Azcón-AguiLAR et al. 1994).

The mycorrhiza formed by Annona plants show an exclusively intracellular hyphal development, with a cell-to-cell colonization pattern, and abundance of arbuscules and coiled hyphae within the cells (AzCón-Aguilar et al. 1994). These characteristics correspond to those described for the Paris species (BRUNDRETT and KendRICK 1990a). Although it has been argued that this type of associations may be less efficient with respect to 
plant growth (BRUNDRETT and KENDRICK 1990b), the results obtained for Annona do not support this assumption (AzCón-AgUILAR et al. 1994).

Research programmes for the improvement of Annona productivity include clonal selection involving micropropagation techniques. Because of the mycorrhizal dependence exhibited by this plant for optimal growth (Azcón-AgUILAR et al. 1994) and the importance of mycorrhiza establishment for the survival and development of most of the plants produced in vitro (GIANINAZZI et al. 1990), the role of mycorrhiza in the development of micropropagated Annona plants was further investigated.

\section{Material and methods}

Cultures of Annona cherimola Mill. cv Fino de Jete were initiated from nodal segments of semi hardwood Annona cuttings using procedures and environmental conditions such as those described by Pliego-Alfaro and Murashige (1987). Shoots were incubated in a basic medium consisting of MS (Murashige and SKOOG 1962) salts supplemented with $(\mathrm{mg} / \mathrm{l})$ : i-inositol $(100)$, thiamine (100), pyridoxine (50), nicotinic acid (50), glycine (200), benzilaminopurine $(0.15), 30 \mathrm{~g} / \mathrm{l}$ sucrose and $8 \mathrm{~g} / \mathrm{l}$ TC agar. Axillar and terminal shoot cuttings $(2.5-3.0 \mathrm{~cm}$ long) were removed from the proliferative clumps and prepared for rooting. Axillary buds and basal leaves of the bottom $1 \mathrm{~cm}$ of the shoots were discarded.

The shoots selected were then placed in $25 \mathrm{x}$ 150 -mm test tubes containing $25 \mathrm{ml}$ of the autoclaved basic medium, to which $1 \mathrm{~g} / \mathrm{l}$ activated charcoal was added. They were incubated in light for three days. Afterwards, they were subcultured in a root induction medium similar to the basic one but supplemented with $15 \mathrm{~g} / \mathrm{l}$ sucrose, 100 $\mathrm{mg} / \mathrm{l}$ indolebutyric acid and $200 \mathrm{mg} / \mathrm{l}$ citric acid. The cultures were then incubated for seven days in darkness and a further three-day period in light. Finally, shoots were subcultured in a root initiation/elongation medium which differed from the basic one in that the MS macroelement amounts were halved and the medium was supplemented with $20 \mathrm{~g} / \mathrm{l}$ sucrose and $200 \mathrm{mg} / \mathrm{l}$ citric acid. Cultures were maintained for approximately two weeks in light.

During rooting, cultures were grown at $26 \pm$ $1{ }^{\circ} \mathrm{C}$, with 16-h light exposure to 2000 lux illumination (Sylvania regular spectrum Gro-Lux lamps). All media were adjusted to $\mathrm{pH} 5.7$ prior to autoclaving at $121^{\circ} \mathrm{C}$ for 15 minutes.

At the end of the root initiation-elongation phase, most plantlets had some roots about $1 \mathrm{~cm}$ long. At this stage, they were brought into acclimatization. Plantlets were individually transplanted to $100 \mathrm{ml}$ open pots containing a mixture of sterile soil-sand $(1 / 1, \mathrm{v} / \mathrm{v})$ and placed in a misting tunnel ( $100 \%$ relative humidity) for four weeks. Afterwards they were transferred to another tunnel without mist for another two weeks. At the end of this period, plants were transplanted to $250 \mathrm{ml}$ pots and transferred to normal greenhouse conditions $\left(25 / 19^{\circ} \mathrm{C}\right.$ day/night temperatures, $16 / 8$ photoperiod, $75 / 90 \%$ relative humidity). Hoagland nutrient solution (HOAGLAND and ARNON 1983 ) at $25 \%$ strength was used to feed the plants at the rate needed to maintain a suitable soil water content.

Mycorrhizal inoculation was assayed at two different stages: (i) immediatelly after the in vitro phase, before starting the acclimatization period, with the aim of establishing the mycorrhizal symbiosis as soon as possible in the ex vitro phase (Experiment 1), and (ii) after the acclimatization phase, before starting the post-acclimatization period under greenhouse conditions (Experiment 2). Mycorrhizal inoculum consisted of thoroughly mixed rhizosphere samples of stock cultures, containing spores, hyphae and mycorrhizal root fragments of the corresponding arbuscular mycorrhizal fungi (AMF).

In Experiment 1, the AMF tested were Glomus mosseae (Nicol. \& Gerd.) Gerd. \& Trappe from Rothamsted Experimental Station (England), Glomus deserticola (Trappe, Bloss \& Menge) from Santiago de Compostela (Spain) and a Glomus sp. from Dijon (France). Inoculation was done by mixing the mycorrhizal inoculum $(10 \mathrm{~g})$ with the soil-sand mixture used to fill the $100 \mathrm{~mL}$ pots. Twenty plantlets per treatment were assayed 
and those that survived after the acclimatization period were allowed to grow for ten weeks.

In Experiment 2, inoculation was done on already acclimatized plantlets $(51.7 \%$ survival rate after acclimatization). Glomus deserticola and Glomus intraradices (Schenck \& Smith) were tested and mycorrhizal inoculation was done when transplanting the plants to the $250 \mathrm{~mL}$ pots. The corresponding inoculum (10 g/pot) was mixed with the soil-sand mixture used as substrate. Ten replicate plantlets per treatment were prepared and allowed to grow for 12 weeks.

During the post-acclimatization phase, timecourse records were kept on the height of the plants and on the number of leaves produced. At harvest, the fresh and dry weights of leaves, stem and roots and the leaf area were recorded and data analysed by ANOVA and Tukey's test. Mycorrhizal colonization was measured on representative stained samples (PHILLIPS and HAYMAN 1970) by the gridline intersect technique (GIOVANNETTI and Mosse 1980).

\section{Results}

Inoculation with $G$. deserticola and Glomus sp. immediately after the in vitro phase (Exp. 1) significantly increased plant height, shoot and root biomass, number of leaves and leaf area (Figs. 1 and 2). However, it did not significantly improve survival of the plantlets ex-vitro. The mycorrhizal effect on leaf number, observed at the end of the acclimatization period (six weeks), appeared before its effect on plant height (Fig. 1). Glomus mosseae, however, did not significantly stimulate plant development (Figs. 1 and 2).

The percentage of mycorrhizal colonization was quite similar for both $G$. deserticola and $G$. mosseae (Fig. 2). However, in some plants G. mosse$a e$ induced abnormal infections characterized by many aborted entry points, which consisted of apparently normal appressoria, but without hyphal penetration of the root tissues. Sometimes few short infective hyphae were produced from the appressoria, but they rapidly aborted, and retracted their cytoplasm, showing septa and emp-
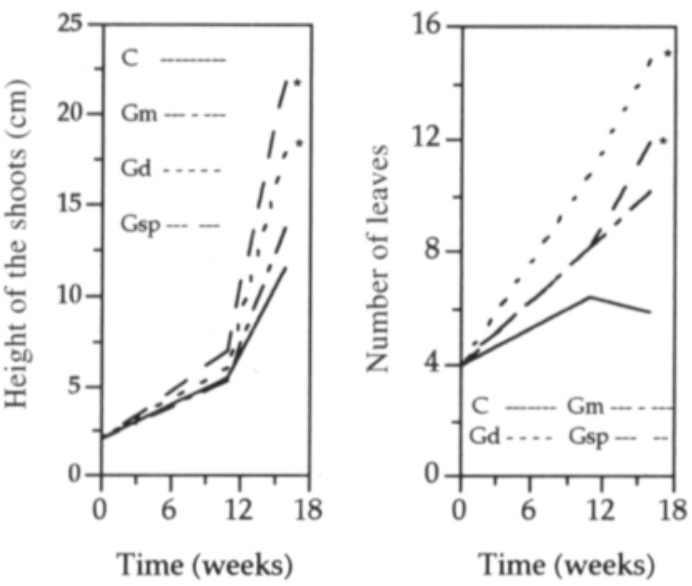

Fig. 1. Shoot height and number of leaves of mycorrhizainoculated $(\mathrm{Gm}=$ Glomus mosseae, $\mathrm{Gd}=$ Glomus deserti cola and Gsp = Glomus sp.) and non- inoculated (C) micropropagated Annona cherimola plants throughout the growth period. Inoculation was done at the beginning of the acclimatization period. * Indicates a significant difference $(\mathrm{P}<0.05)$ according to Tukey's test.

ty hyphal tips. These infective hyphae were unable to spread in the root cortex and to establish arbuscules. In some other cases, a very intense, and disorganized fungal colonization of the root was observed. This infection seemed to be outside host control because some meristematic and vascular tissues appeared to be colonized by the fungus. Not all plants colonized by $G$. mosseae exhibited these abnormal patterns of colonization. In some cases, as in those of mycorrhizal associations with $G$. deserticola and Glomus sp., the colonization pattern showed a morphology similar to the one described for plants derived from seeds, with the cell-to-cell passage, and the abundance of arbuscules and coiled hyphae within cells, which are typical of this host species.

The influence of $G$. deserticola when increasing the leaf area/leaf fresh weight ratio (Fig. 2) is noteworthy. This effect was not significantly induced by Glomus sp., although the effects of both fungi on plant growth were quite similar.

The mycorrhiza-induced increases in plant growth and development were even higher when mycorrhizal endophytes were inoculated after the acclimatization period (Exp. 2, Figs. 3 and 4). As in Experiment 1, the mycorrhizal effect on the 

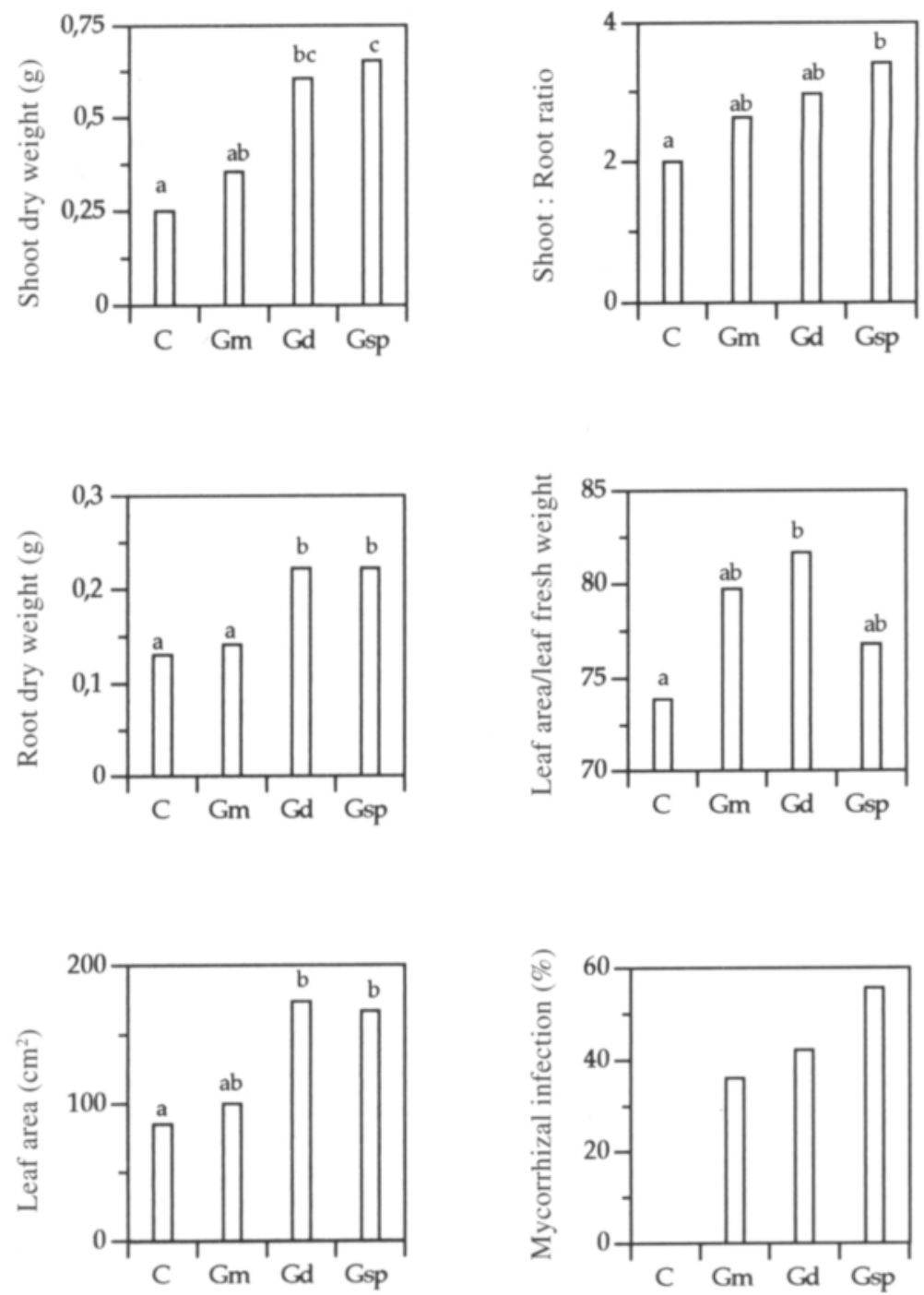

\section{Treatments}

Fig. 2. Biomass production and distribution, leaf area and mycorrhizal infection of inoculated (Gm $=$ Glomus mosseae, $\mathrm{Gd}=$ Glomus deserticola and $\mathrm{Gsp}=$ Glomus $\mathrm{sp}$.$) and non-inoculated (\mathrm{C})$ micropropagated Annona cherimola plants . Inoculation was done at the beginning of the acclimatization period. For each parameter, values sharing the same letter did not differ significantly $(\mathrm{P}<0.05)$ according to Tukey's test.

leaf number was detected before its effect on plant height (Fig. 3). All of the growth parameters measured significantly increased with mycorrhizal inoculation in all of the assayed endophytes (Figs. 3 and 4). As in Experiment 1, G. deserticola increased the leaf area/leaf fresh weight ratio.
If all the data from these experiments and from others carried out on the same plant (AzCón-AGUILAR et al. 1994 and unpublished results), were pooled, it would be observed that the effect of mycorrhizal inoculation on plant height, given as percentage increase over control, is much higher 

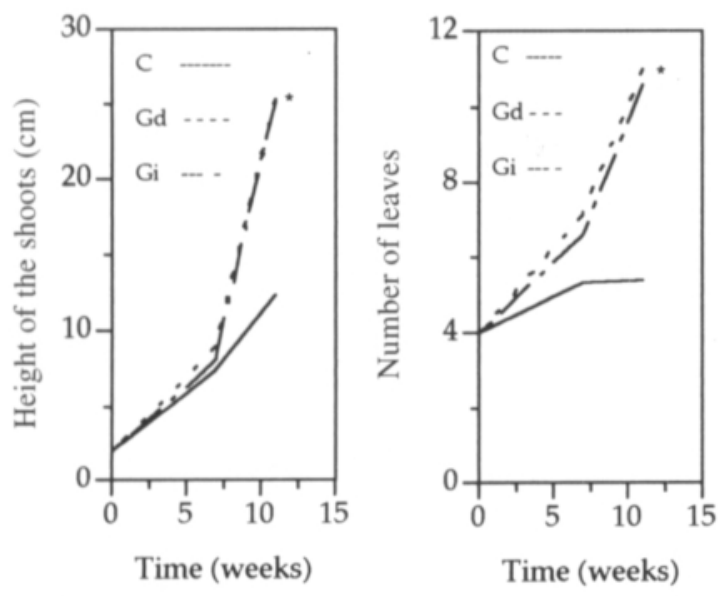

Fig. 3. Effect of different mycorrhizal fungi $(\mathrm{Gd}=$ Glomus deserticola, $\mathrm{Gi}=$ Glomus intraradices and $\mathrm{C}=$ non-inoculated control) on shoot height and number of leaves in micropropagated plants of Annona cherimola throughout the growth period. Inoculation was done at the end of the acclimatization period. * Indicates a significant difference $(\mathrm{P}<0.05)$ according to Tukey's test.

for micropropagated plants than for those propagated from seeds (Fig. 5). This suggests that micropropagated Annona plants are even more dependent on mycorrhiza formation for optimal growth than plants derived from seeds.

\section{Discussion}

Most of the AMF assayed substantially increased shoot and root biomass and leaf area, corroborating the strong dependence of Annona cherimola on mycorrhiza for optimal growth (AzCóN-AGUILAR et al. 1994). In addition to the general effect of improving plant growth, G. deserticola consistently enhanced the leaf area/leaf fresh weight ratio. This suggests that other mechanisms, apart from the increased nutrient uptake, could be involved in the effect that $G$. deserticola exerts on plant development. Plant hormone production (BAREA and AzCón-Aguilar 1982) or changes in- duced in the hormonal balance of the plant (DIXON 1990) may underly some of these mechanisms.

The fact that mycorrhizal dependence is greater for micropropagated plants than for those propagated from seeds can be explained on the basis of the different types of stresses (nutritional, drought, etc.) to which a micropropagated plant is subjected. In order to cope with these stresses, they depend to a greater extent on mycorrhiza during the post-vitro growth.

In relation to the inoculation time, plants benefited more from mycorrhiza inoculation when the AMF were introduced after the acclimatization period. When AMF were inoculated immediately after the in vitro phase, mycorrizal colonization showed, in some cases, either aborted infection or very intense colonization, apparently outside the control of the host. It seems as if some roots (or some plantlets) were not yet mature enough to control the growth of the AMF in the root tissues and, consequently, to establish the symbiosis. Thus, they react against the fungus (abortive infection) and, if they fail to avoid infection, it appears rather disorganized and uncontrolled. Under these conditions, mycorrhiza formation could not induce beneficial effects on plant development, or it might even provoke detrimental ones. This reaction was found for $G$. mosseae -inoculated plants in some cases, although, in others, plants showed normal colonization patterns and growth increases. This suggests that this effect appears as a consequence of the physiological status of the plantlets and not as a specific reaction against $G$. mosseae. In fact, G. mosseae improved Annona cherimola growth in other circumstances (AzCón-Aguilar et al. 1994).

Studies are now underway to confirm these facts and to determine the physiological status required for the root system to be able to establish a functional mycorrhizal symbiosis in micropropagated plants.

Acknowledgements. This study was supported by CICYTSpain (Project AGR 91 - 0605-C02-01). 

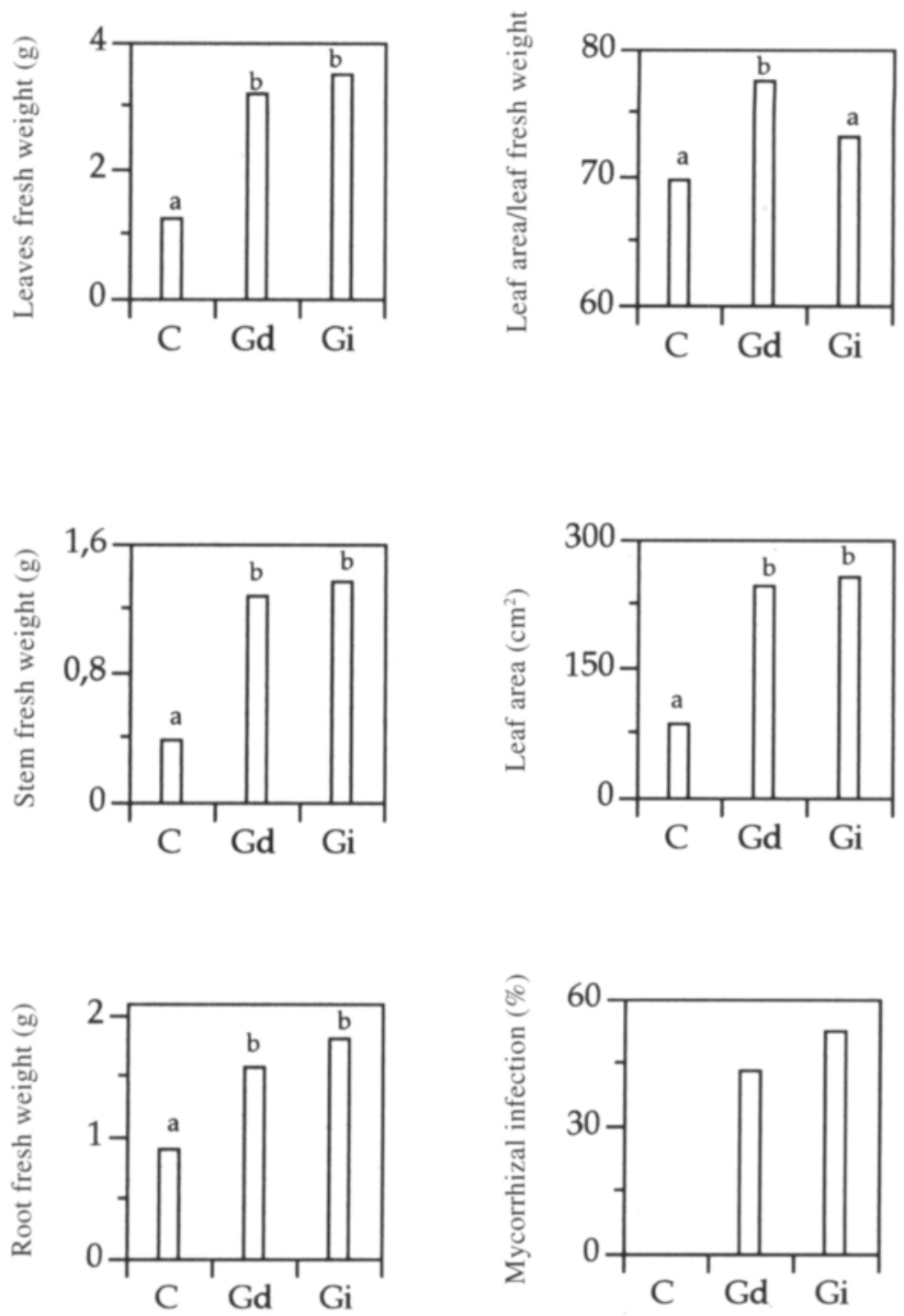

\section{Treatments}

Fig. 4. Biomass production, leaf area and mycorrhizal infection of inoculated $(\mathrm{Gd}=$ Glomus deserticola and $\mathrm{Gi}=$ Glomus intraradices) and non-inoculated (C) micropropagated Annona cherimola plants. Inoculation was done at the end of the acclimatization period. For each parameter, values sharing the same letter did not differ significantly $(\mathrm{P}<0.05)$ according to Tukey's test.

\section{References}

Azcón-Aguilar, C., Encina, C.L., Azcón, R. \& Barea, J. M. 1994. Mycotrophy of Annona cherimola and the morphology of its mycorrhizae. Mycorrhiza 4: 161168.
Barea, J. M. \& Azcón-Aguilar, C. 1982. Production of plant growth-regulating substances by the vesiculararbuscular mycorrhizal fungus Glomus mosseae. Appied and Environmental Microbiology 43: 810-813. 


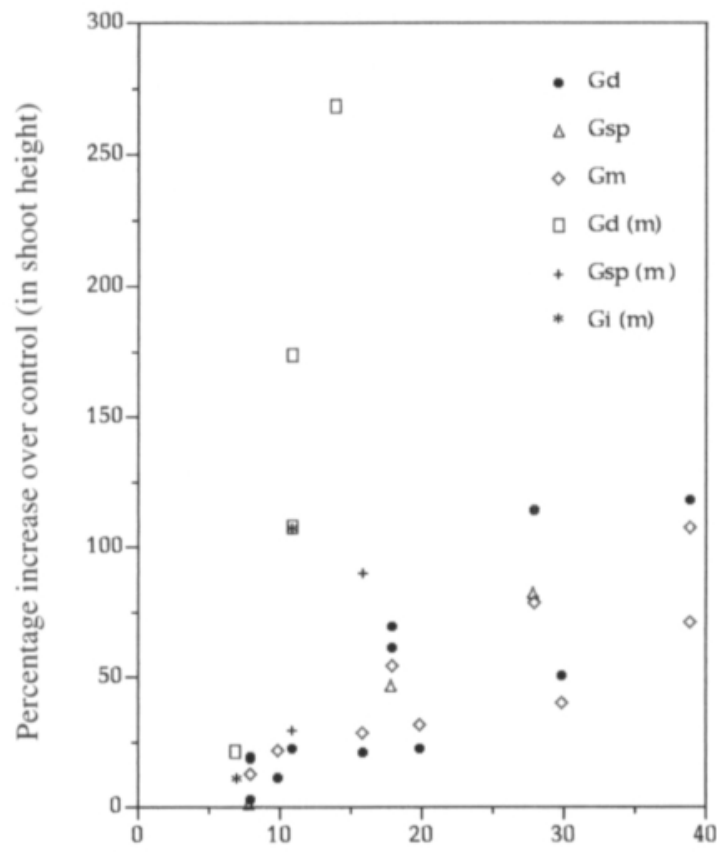

Time (weeks)

Fig. 5. Percentage increase of shoot height induced over control by different mycorrhizal fungi $(\mathrm{Gm}=$ Glomus mosseae, $\mathrm{Gd}=$ Glomus deserticola and $\mathrm{Gsp}=$ Glomus $\mathrm{sp}$.) in different experiments, using micropropagated $(\mathrm{m})$ and seed-propagated Annona cherimola plants.

Brundrett, M. \& Kendrick, B. 1990a. The roots and mycorrhizas of herbaceous woodland plants. I. Quantitative aspects of morphology. The New Phytologist 114: $457-468$.

- \& KendRICK, B. 1990b. The roots and mycorrhizas of herbaceous woodland plants. II. Structural aspects of morphology. The New Phytologist 114: 469-479.

Dixon, R.K. 1990. Cytokinin activity in Citrus jambhiri seedlings colonized by mycorrhizal fungi. Agriculture, Ecosystems and Environment 29: 103-106.

Gaussen, H., Leroy, J. F. \& Ozenda, P. 1982. Précis de Botanique. In: Grassé, P. P. (ed.). Végétaux supérieurs. Masson, Paris. p. 221-230.

Gianinazzi, S., Gianinazzi-Pearson, V. \& Trouvelot, A. 1990. Potentialities and procedures for the use of endomycorrhizas with special emphasis on high value crops. In: Whipps, J.M. et al. (eds.). Biotechnology of fungi for improving plant growth. University Press, Cambridge. p. 41-54.

Giovanetti, M. \& Mosse, B. 1980. An evaluation of tech- niques for measuring vesicular-arbuscular mycorrhizal infection in roots. The New Phytologist 84: 489-500.

Hoagland, D.R. \& ARNON, D. I. 1983.The water culture method for growing plants without soil. 347 p. Calif. Agr. Exp. Sta. Cir. Berkeley, California.

MORTON, J.F. 1987. Fruits of warm climates. In: Dowling, C. F. (ed.). Florida. 505 p.

Murashige, T. \& Skoog, F. 1962. A revised medium for rapid growth and bioassays with tobacco tissue culture. Physiologia Plantarum 15: 473-497.

Phillips, J.M. \& HaYman, D. S. 1970. Improved procedures for clearing roots and staining parasitic and vesicular-arbuscular mycorrhizal fungi for rapid assessment of infection. Transactions of the British Mycological Society 55: 159-161.

Pliego-Alfaro, F. \& Murashige, T. 1987. Possible rejuvenation of adult avocado by graftage onto juvenile rootstocks in vitro. HortScience 22: 1321-1324

Manuscript received December 1993 


\title{
SELOSTUS
}

\section{Arbuskelimykorritsasienten vaikutus mikrolisätyn annoonan (Annona cherimola) kasvuun ja kehitykseen}

\author{
Concepcion Azcón-Aguilar, C.L. Encina, R. Azcón ja Jose Miguel Barea \\ Estación Experimental del Zaidín ja Estación Experimental La Mayora, Espanja
}

\begin{abstract}
Annona eli kirimoija (Annona cherimola Mill.) on kiinnostava trooppinen hedelmäkasvi. Espanjassa kehitettiin kasvin mikrolisäystä, että kasvin kloonivalintaa voitaisiin tehdä sadontuottokyvyn parantamiseksi. Annona tarvitsee mykorritsaa saavuttaakseen optimaalisen kasvun. Aikaisemmissa kokeissa on todettu mykorritsasiirrostuksen lisäävän annoonan pikkutaimien henkiinjäämistä ja kehitystä.

Tämän tutkimuksen tavoitteena oli selvittää arbuskelimykorritsasienten siirrostuksen vaikutusta mikrolisätyn annoonan kasvuun ja kehitykseen. Kasvit siirrostettiin kah-
\end{abstract}

tena ajankohtana, joko välittömästi taimien in vitro -vaiheen jälkeen ennen sopeuttamista jatkoviljelyolosuhteisiin tai sopeuttamisjakson jälkeen. Sopeuttamisvaiheen jälkeen taimien eloonjäämisprosentti oli vain n. 50. Mykorritsa paransi taimien kasvua ja kehitystä. Useimmat käytetyt sienikannat lisäsivät huomattavasti versojen ja juurten biomassaa sekä lehtialaa. Mikrolisätyillä Annona-taimilla näyttää olevan suurempi riippuvuussuhde mykorritsan kanssa kuin siemenistä kasvatetuilla taimilla. Mykorritsasienten vaikutus oli vahvin silloin, kun siirrostus tehtiin sopeuttamisjakson jälkeen. 